\title{
Effect of drain effluents on hardness of water of the ponds of Varanasi
}

\section{- SANJU DWIVEDI}

Article Chronicle:

Received :

16.05.2017;

Revised :

11.11.2017;

Accepted :

21.11.2017

\section{Key Words :}

Effluents, Heavy

metals, Hardness
ABSTRACT : Water is necessity of all living being, it helps in the digestion of food as well as provides necessary minerals required to the body. But, harden water has its demerits on human life both ways for drinking as well as for normal use. The soap consumption requires a high budget and accumulation of harmful metals in excess may damage the human health. In ponds there are greater chances of heavy metals like $\mathrm{Ca}, \mathrm{Ba}, \mathrm{Sr}, \mathrm{Mg}$, Fe etc. which are conveyed to ponds through drains. The quantitative monitoring of such heavy metals which render hardness to ponds water is essential. In the present dissertation periodic estimations of Varanasi city have been made and the utility results have been drawn their from. In the undertaken study sites the heavy metals except Ca were obtain in extremely trace amounts.

HOW TO CITE THIS ARTICLE : Dwivedi, Sanju (2017). Effect of drain effluents on hardness of water of the ponds of Varanasi. Asian J. Environ. Sci., 12(2): 90-92, DOI: 10.15740/HAS/AJES/12.2/90-92.
Author for correspondence :

\section{SANJU DWIVEDI}

Department of Chemistry, S.M.W's College

Kerakatpur, VARANASI (U.P.) INDIA

Email : sanjudwivedi30@ gmail.com 